\title{
ポリエチレングリコール，プロピレングリコールおよびそのメチルエーテル の同族体の表面張力一一分子量依存性とメチル基効果
}

\author{
紬村 知之*1 ・畑 敏雄*2
}

(受付 1975 年 12 月 15 日・審查終了 1976 年 1 月 28 日)

\begin{abstract}
要 旨 ポリエチレングリコール(PEG), ポリプロピレングリコール(PPG) とそのメチルエーテル 同族体の表面張力を種々の温度で，静泡法で測定した。そして表面張力の分子量依存性とメチル基の 効果について議論する。.PEG の表面張力 $(\gamma)$ は分子量に依存せず, そのモノメチルエーテルとジメ チルェーテルの $\gamma$ は分子量とともに增加する.PPGの場合には $\gamma$ は分子量とともに減少し, そのモ ノメチルェーテルについては増加した。これ㞦の事実は, 絽返し単位と末端基との表面張力成分の加 成性にもとうく畑の式によって説明される。メチル基は綝返し単位に抢いても，末端基に㧍いても， 表面張力を下げるよ5に作用する. PEG, PPG および PIBG(ポリイソブチレングリコール) の繰り 返し単位の $\gamma$ はそれぞれ 42.7, 31.0, $27.2 \mathrm{dyn} / \mathrm{cm}$ と推定された。 そして末端の水酸基とメトキシ 基の $\gamma$ は 42 44, 11 13 dyn $/ \mathrm{cm}$ となった。 パラコールと分子容の加成性も示された. マクレオー ド指数（ $\beta$ ）は分子量とともに減少し， $\mathrm{d} \ln \gamma / \mathrm{d} T=\alpha \cdot \beta$ の関倸は実験的に示されたにここで $\alpha$ は熱膨 張保数である).
\end{abstract}

\section{1 緒言}

A.K. Rastogi と L.E. ST. Pierre ${ }^{1)}$ はポリエチレング リコールとポリプロピレングリコールの表面張力の測定 を行い，その表面張力が分子量によって変化しないこと を見いだし，その理由を末端水酸基間の会合による高分 子量化にあるとした．しかし水酸基間に会合が起こると しても，もしそらであれば，ポリエチレングリコールの 繰返し単位 - $\left[-\mathrm{CH}_{2}-\mathrm{CH}_{2}-\mathrm{O}-\right]-$ とチレングリコール の会合体の繰返し単位<smiles>[3H]CCO[Hg]O[AlH2]</smiles>

とは構造において異なり，したがって表面張力への寄与 も当然異ならなければならない。ゆえに水酸基による会 合によって分子量依存性のないことを説明する試みは一 般的に成立するとはいいがたい。

一方, 畑 ${ }^{2}$ は高分子融体の表面張力の分子量依存性を 解析して, 繰返し単位と末端基の寄与の加成性から種々 の実験事実を説明した，本研究はこの立場からポリエチ レングリコール，ポリプロピレングリコールおよびその 同族体の分子量依存性を説明し, 繰返し単位と末端基の 寄与を明らかにしようとするものである. 併せてメチル 基が分子末端に存在する場合と側鎖に存在する場合の相 違を議論する.

*1 岐阜大学工学部( 504 各務原市那加門前町)

*2 群馬大学工学部 (376 桐生市天神町)

\section{2 実験}

\section{1 試料}

本研究で用いた試料を Table 1 に示す. ポリエチレ ングリコールとしては分子量が $200,400 ， 600$ の3 種 (これを PEG 系と呼ぶ), PEG のモノメチルエーテル としては monomer (EG-MM), dimer (2EG-MM), trimer (3EG-MM) の 3 種 (これを EG-MM 系と呼 ぶ), また PEG のジメチルェーテルとして monomer (EG-DM), dimer (2EG-DM), trimer (3EG-DM), tetramer (4EG-DM) および分子量が 350, 550, 750 の ポリマー (PEGーDM 350 など)（これを PEG-DM 系 と呼ぶ) である.

ポリプロピレングリコールとしては monomer(PG), dimer (2PG), trimer (3PG) および分子量が 425,1025 のポリマー(PEG 425 など) (これをPPG 系と呼ぶ)で ある. PPG のモノメチルェーテルとして monomer (PG-MM), dimer (2PG-MM), trimer (3PG-MM) の 3 種 (これを $\mathrm{DG}-\mathrm{MM}$ 系と呼ぶ) である. 以上の試 料は市販のものを使用したが, Table 1 にその規格を示 す.これらのらちガスクロ用 (GC) のものと試薬特級 (GR) のものはそのまま使用し, 試薬一級 (EP) につい ては減压蒸留して用いた。 ポリイソブチレングリコール (PIBG) は分子量 3 万のもので $\mathrm{D}$ 社より提供されたる のである.

\section{2 実験方法}

表面張力の測定は静泡法で行い, 北崎と畑 ${ }^{8)}$ の考案し 
エチレングリコール，プロピレングリコールおよびそのメチルエーテル同族体の表面張力

Table 1. Samples used.

\begin{tabular}{lllrl}
\hline \hline & \multicolumn{1}{c}{ Sample } & Symbol & $M_{w}$ & Grade* \\
\hline \multirow{3}{*}{ PEG series } & Poly(ethylene glycol) 200 & PEG 200 & 200 & GC \\
& Poly(ethylene glycol) 400 & PEG 400 & 400 & EP \\
& Poly(ethylene glycol) 600 & PEG 600 & 600 & EP \\
\hline \multirow{4}{*}{ EG-MM series } & Ethylene glycol monomethyl ether & EG-MM & 76 & GR \\
& Diethylene glycol monomethyl ether & 2EG-MM & 134 & EP \\
& Triethylene glycol monomethyl ether & 3EG-MM & 164 & EP \\
\hline & Ethylene glycol dimethyl ether & EG-DM & 90 & GR \\
& Diethylene glycol dimethyl ether & 2EG-DM & 134 & EP \\
& Triethylene glycol dimethyl ether & 3EG-DM & 178 & GR \\
& Tetraethylene glycol dimethyl ether & 4EG-DM & 222 & EP \\
& Poly(ethylene glycol) dimethyl ether 350 & PEG-DM 350 & 350 & GC \\
& Poly(ethylene glycol) dimethyl ether 550 & PEG-DM 550 & 550 & GC \\
& Poly(ethylene glycol) dimethyl ether 750 & PEG-DM 750 & 750 & GC \\
\hline \multirow{5}{*}{ PPG series } & Propylene glycol & PG & 76 & EP \\
& Dipropylene glycol & 2PG & 134 & EP \\
& Tripropylene glycol & $3 P G$ & 164 & EP \\
& Poly(propylene glycol) 425 & PPG 425 & 425 & GC \\
& Poly(propylene glycol) 1025 & PPG 1025 & 1025 & GC \\
\hline \multirow{3}{*}{ PG-MM } & Propylene glycol monomethyl ether & PG-MM & 90 & EP \\
& Dipropylene glycol monomethyl ether & 2PG-MM & 148 & EP \\
& Tripropylene glycol monomethyl ether & 3PG-MM & 206 & EP \\
\hline
\end{tabular}

*: GC, for gaschromatography; GR, guaranteed reagent; EP, extra pure.

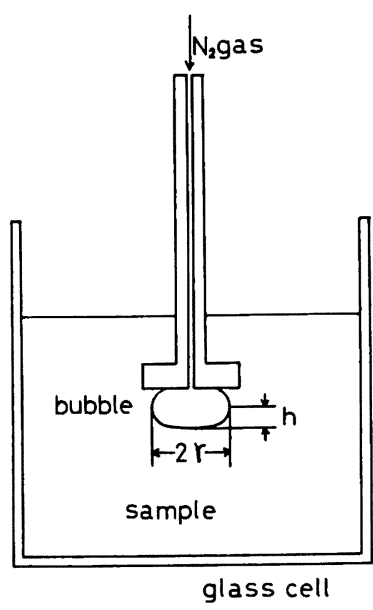

Fig. 1. Schema of sessile bubble method of the surface tension measurement.

た装置を用いた，装置のセル部分を Fig. 1 に示す. 試 料を入れたこのガラスセルを到素ガスを満した容器中の
支持台に載せ，この支持台をジャッキによって持ち上げ て，あらかじめ水平に保持された金属プレートを浸せき する. プレートの大きさは直径 $15 \mathrm{~mm}$ で，その中央の 直径 $1 \mathrm{~mm}$ の穴から窒素ガスを送り気泡をつくる. 容器 全体は適当な温度に制御された空気恒温槽の中に入れて ある。

恒温槽および容器ののぞき空からカセトメーターで気 泡の最大半径 $(r)$ と $r$ を含む面からメニスカスの頂点 までの距離 $(h)$ を测定する. 表面張力 $(\gamma)$ の計算は次の Porter ${ }^{4)}$ の式によった.

$$
r=\Delta \rho g h^{2}\left\{0.500-0.3047 \frac{h}{r}+1.219\left(\frac{h}{r}\right)^{3}\right\}
$$

ここで， $\Delta \rho$ は試料の気体状態と液体状態の密度差, $g$ は重力加速度である.

この静泡法は毛管上昇法や du Noüy 法では困難な高 分子溶融体の表面張力の測定に最も適しており, 高温で の測定も可能である点も有利である.

密度の測定は常温付近ではピクノメーターを用い, 高 温域ではディラトメトリーを使用した。

表面張力の測定は一般に $25 \sim 110^{\circ} \mathrm{C}$ の間で行った. 


\section{3 実験 結果}

\section{1 表面張力の温度依存性}

Fig. 2 に PEG 系と PEG-DM 系, Fig. 3 に PPG 系, Fig. 4 に EG-MM 系と PG-MM 系, Fig. 5 に PIBG の表面張力と温度の関係を示す.一般に表面張力 と温度の間には次の関係がある.

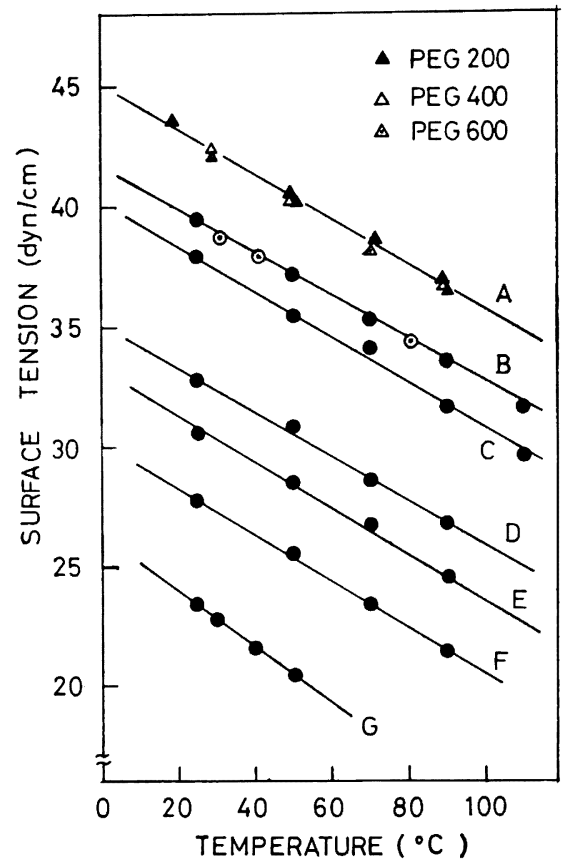

Fig. 2. Temperature dependence of surface tension: A, PEG series; B, PEG-DM 750; C, PEG-DM 350; D, 4EG-DM; E, 3EG-

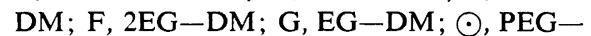
DM 550 .

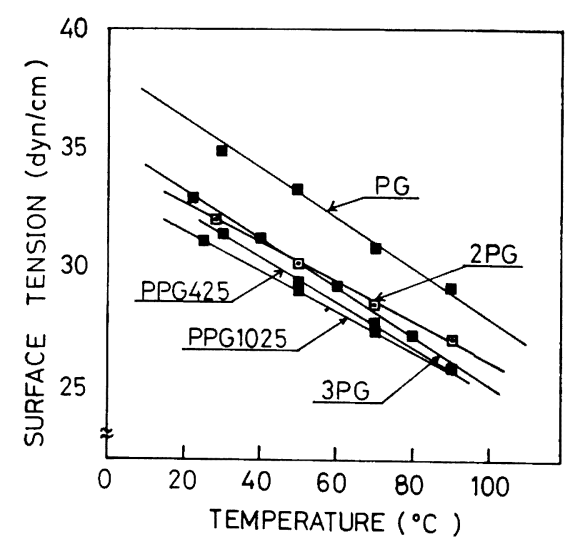

Fig. 3. Temperature dependence of surface tension of PPG series.

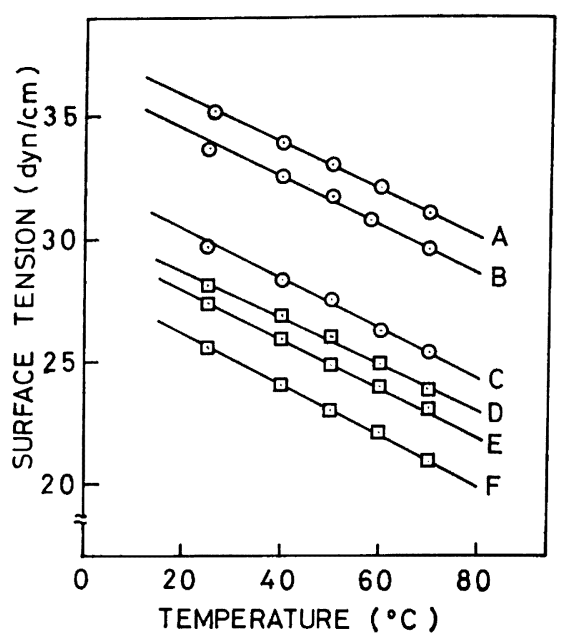

Fig. 4. Temperature dependence of surface tension of EG-MM series and PG-MM series:

A, 3EG-MM; B, 2EG-MM; C, EG-MM;

D, 3PG-MM; E, 2PG-MM; F, PG-MM.

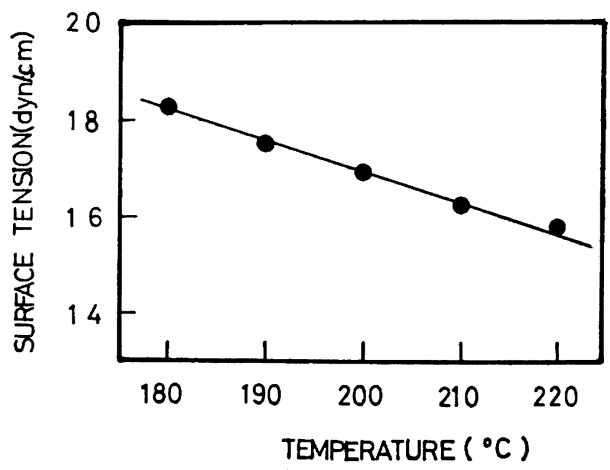

Fig. 5. Temperature dependence of surface tension of PIBG.

$$
r=E^{S}-S^{S} T
$$

ここで, $E^{S}$ は表面エネルギー, $S^{S}$ は表面エントロピ 一, $T$ は絶対温度である.いずれの場合にも良い直線関 係がある. また (2) 式から明らかなように，rの $T \rightarrow 0$ への外乞う值は $E^{S}$ を与え, $r$ の温度こう配は $S^{S}$ を与 える.

各試料に対する $E^{S}, S^{S}$ および $25^{\circ} \mathrm{C}$ に扑ける表面張 力の值を Table 2 に示す.

\section{2 表面張力の分子量依存性}

$25^{\circ} \mathrm{C}$ における表面張力と分子量の関係を Fig. 6 に 示寸.

PEG 系については A.K. Rastogi ${ }^{1)}$ らのデータを併 せて示したが $\gamma$ の分子量依存性はほとんど見られない。 
エチレングリコール，プロピレングリコールおよびそのメチルエーテル同族体の表面張力

Table 2. Surface tensions, surface energies, surface entropies, densities and other surface properties.

\begin{tabular}{|c|c|c|c|c|c|c|c|c|}
\hline Sample & $\begin{array}{l}\gamma\left(25^{\circ} \mathrm{C}\right) \\
(\mathrm{dyn} / \mathrm{cm})\end{array}$ & $\begin{array}{c}E^{S} \\
\left(\mathrm{erg} / \mathrm{cm}^{2}\right)\end{array}$ & $\begin{array}{c}S^{S} \\
\left(\operatorname{dyn} / \mathrm{cm}^{\circ} \mathrm{C}\right)\end{array}$ & $\begin{array}{c}\rho \\
\left(25^{\circ} \mathrm{C}\right)\end{array}$ & $\begin{array}{l}\alpha \\
\times 10^{-3}\end{array}$ & $\beta$ & $\begin{array}{c}\alpha \beta \\
\times 10^{-3} \\
\end{array}$ & $\mathrm{~d} \underset{\times 10^{-3}}{\ln \gamma / \mathrm{d} T}$ \\
\hline PEG 200 & 43.0 & 72.3 & 0.098 & 1.125 & 0.774 & 3.1 & 2.4 & 2.4 \\
\hline PEG 400 & 42.8 & 71.6 & 0.097 & 1.123 & 0.802 & 3.0 & 2.4 & 2.4 \\
\hline PEG 600 & 42.6 & 70.8 & 0.095 & 1.123 & 0.810 & 2.9 & 2.4 & 2.4 \\
\hline EG-MM & 29.8 & 61.0 & 0.105 & 0.963 & 1.020 & 3.7 & 3.8 & 3.6 \\
\hline 2EG-MM & 34.1 & 62.8 & 0.096 & 1.031 & 0.909 & 3.4 & 3.1 & 3.0 \\
\hline $3 \mathrm{EG}-\mathrm{DM}$ & 35.4 & 62.9 & 0.092 & 1.045 & 0.899 & 3.1 & 2.8 & 2.8 \\
\hline $\mathrm{EG}-\mathrm{DM}$ & 23.5 & 54.7 & 0.105 & 0.865 & 1.215 & 4.4 & 5.4 & 5.3 \\
\hline $2 \mathrm{EG}-\mathrm{DM}$ & 27.8 & 56.6 & 0.097 & 0.944 & 1.033 & 4.4 & 4.5 & 4.5 \\
\hline $3 E G-D M$ & 30.6 & 59.1 & 0.095 & 0.985 & 0.953 & 4.2 & 4.0 & 3.4 \\
\hline $4 E G-D M$ & 32.8 & 61.9 & 0.093 & 1.018 & 0.916 & 3.9 & 3.6 & 3.0 \\
\hline PEG-DM 350 & 37.9 & 65.0 & 0.091 & 1.087 & 0.760 & 3.9 & 3.0 & 2.9 \\
\hline PEG-DM 550 & 38.9 & 66.0 & 0.089 & 1.096 & 0.733 & 3.5 & 2.6 & 2.6 \\
\hline PEG-DM 750 & 39.5 & 65.6 & 0.088 & 1.109 & 0.744 & 3.4 & 2.5 & 2.6 \\
\hline PG & 35.4 & 64.9 & 0.098 & 1.039 & 0.800 & 3.8 & 3.0 & 2.9 \\
\hline 2PG & 32.4 & 57.7 & 0.085 & 1.021 & 0.840 & 3.6 & 3.0 & 2.8 \\
\hline 3PG & 32.6 & 61.4 & 0.097 & 1.019 & 0.875 & 3.6 & 3.2 & 3.1 \\
\hline PPG 425 & 31.6 & 57.9 & 0.088 & 0.999 & 0.883 & 3.6 & 3.2 & 3.2 \\
\hline PPG 1025 & 31.2 & 56.5 & 0.085 & 1.002 & 0.878 & 3.4 & 3.0 & 2.8 \\
\hline PG-MM & 25.7 & 56.6 & 0.1037 & 0.919 & 1.115 & 4.2 & 4.6 & 4.6 \\
\hline $2 \mathrm{PG}-\mathrm{MM}$ & 27.5 & 56.6 & 0.0978 & 0.948 & 1.017 & 3.8 & 3.9 & 3.9 \\
\hline $3 P G-M M$ & 28.2 & 56.7 & 0.0958 & 0.963 & 0.959 & 3.6 & 3.5 & 3.6 \\
\hline PIBG & $27.2 *$ & 46.9 & 0.066 & & 0.950 & 3.8 & 3.6 & 3.9 \\
\hline
\end{tabular}

* extrapolation from melting state.

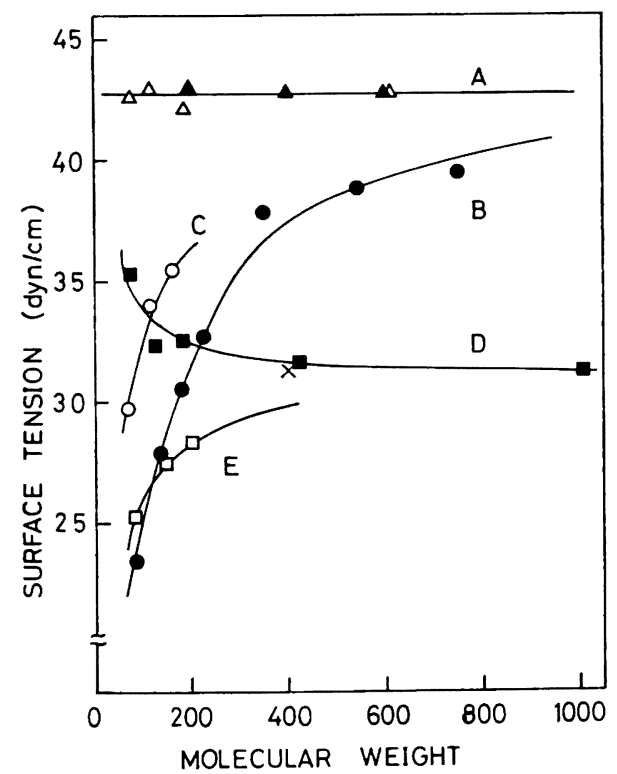

高分子論文集, Vol. 33, No. 4 (1976)
EG-MM, PEG-DM, および PG-MM では $\gamma$ は分 子量の増加とともに大きくなるが，PPG 系では分子量 とともに減少している. A.K. Rastogi ${ }^{11}$ らはPPG 系 のrには分子量依存性がないといっているが，彼らのデ 一タは $M>400$ の範囲であり，より低分子量域で， 分子量とともに急速に減少する. ここで $2 \mathrm{PG}$ のては異 常に小さな値となった. A.F. Gallaugher ${ }^{5)}$ らはジェ チレングリュールでは両末端の水酸基が会合して環状の 分子となるためにrの值が異常に小さくなることを示し たが，2PG についても同様に水酸基の会合によって環 状の分子となるため末端の水酸基による表面張力への寄 与が制限されて，r の值が小さくなるものと思われる.

Fig. 6. Molecular weight dependence of surface tension at $25^{\circ} \mathrm{C}$ : A, PEG series $(\boldsymbol{A}$, by authors; $\triangle$, by A. K. Rastogi et al. ${ }^{1)}$ ), B, PEG-DM series; C, EG-MM series; D, PPG series ( $\boldsymbol{\square}$, by authors; $\times$, by A. K. Rastogi et al. ${ }^{1)}$ ); E, PG-MM series. 


\section{3 密度と熱脚張蚛}

$25^{\circ} \mathrm{C}$ に批る密度 $(\rho)$ と熱膨張率 $(\alpha)$ のデータを Table 2 に示す. 密度は PEG 系ではほとんど变化な く, EG-MM 系, PEG-DM 系, PG-MM 系では 分子量の增加とともに大きくなり，PPG 系では分子量 とともに小さくなった，この傾向は表面張力の場合と同 じである. 一方, 熱膨張率は密度とは逆の傾向を示し, PEG 系, PPG 系では分子量とともに增加するが, EGMM 系 PEG-DM 系, PG-MM 系では分子量と ともに減少している. 両末端が水酸基である PG P PEG 系では $\alpha$ は小さい，分子量の同じ位の PEG $200(\alpha=$ $\left.0.774 \times 10^{-3}\right), 3 \mathrm{EG}-\mathrm{MM}\left(0.899 \times 10^{-3}\right), \quad 3 \mathrm{EG}-\mathrm{DM}$ $\left(0.953 \times 10^{-3}\right)$ を比較すると末端のメチル基が增加する に従って $\alpha$ は大くなっている. また PG $\left(0.800 \times 10^{-3}\right)$ と PG-MM $\left(1.115 \times 10^{-3}\right)$ との比較でも同じことがい える. 側鎖メチル基についても PEG $400\left(0.802 \times 10^{-3}\right)$ と PPG $425\left(0.883 \times 10^{-3}\right)$ の比較からメチル基が入る と $\alpha$ は大きくなる.

\section{4 考察}

\section{1 表面張力の分子量依存性について}

Sugden $^{6)}$ はよく知られているようにパラコール (P) の概念を導入して表面張力と分子量 $(M)$ 扣よび密度差 $\left(\rho_{L}-\rho_{G}=\Delta \rho\right)$ との関係式を次のよ5に表した。

$$
\gamma=\left(\frac{\left(\rho_{\mathrm{L}}-\rho_{\mathrm{G}}\right) P}{M}\right)^{4}
$$

高分子域では $\rho_{\mathrm{G}}$ は無視できるので $\rho_{\mathrm{L}} / M=1 / V(V$ は分 子容）と扰いて

$$
r=\left(\frac{P}{V}\right)^{4}
$$

指数 4 は一般的には $\beta$ とおかれ MacLeod 指数と呼ば れる. 烟到は $P$ と $V$ を繰返し単位の寄与 $P_{\mathrm{m}}, V_{\mathrm{m}}$ と 末端基の寄与 $P_{\mathrm{e}}, V_{\mathrm{e}}$ に分けて, それらの加成性から $\gamma$ の重合度依存性を次式の上うに導いた。

$$
\gamma=\gamma_{\mathrm{m}}\left[1+\frac{2 \beta k}{n}\left\{\left(\frac{\gamma_{\mathrm{\theta}}}{\gamma_{\mathrm{m}}}\right)^{1 / \beta}-1\right\}\right]
$$

ここで $k$ は $V_{\mathrm{e}} / V_{\mathrm{m}}$ である.この式によれば $\gamma_{\mathrm{e}}$ と $r_{\mathrm{m}}$ の大小関係によって, $\gamma_{\theta}>\gamma_{m}$ ならば重合度 $n$ とともに $\gamma$ は減小し, $\gamma_{\mathrm{e}}<r_{\mathrm{m}}$ ならば $n$ とともに增加し, $\gamma_{\mathrm{e}}=\gamma_{\mathrm{m}}$ のときての分子量依存性はない。これらすべての場合が 実際に起こりらることは Bascom ${ }^{7)} の ~ n$-alkane, $n$-alkyl benzene, $n$-alkyl diphenyl などの実験をみても明らか で，烟によって合理的に証明された。一方，Gains ${ }^{8)} ら$ はrの分子量依存性として,

$$
r=r_{\infty}-\frac{A}{M^{2 / 3}}
$$

を与えているが, 彼らの誘導では $A$ は常に正で, した がって分子量とともにてが增加する場合しか説明できな い.

また $\log r$ と $\log M$ の関係も Fig. 7 に示すよ5に 2/3 のこう配をもたない（5) 式から分かるようにこのこ 配は $k \beta, r_{\mathrm{e}} / r_{\mathrm{m}}$ の関数であり一定値とはならない。

Fig. 6 を $1 / M$ に対してプロットすると Fig. 8 とな る. (5) 式は可変な $\beta$ を含むので䇺密に $\gamma \propto 1 / M$ と はならないが(とくに低分子量域において)，およそこの 関係が成り立つことが分かる. $\beta$ が可変であるにもかか わらずこのようになるのは（5) 式における $1 / n$ の保数

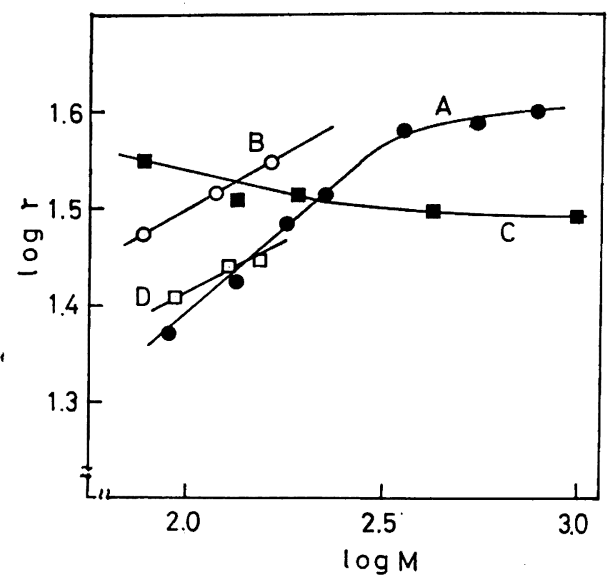

Fig. 7. $\log \gamma$ vs. $\log M$ at $25^{\circ} \mathrm{C}:$ A, PEG-DM series; B, EG-MM series; C, PPG series; $D, P G-M M$ series.

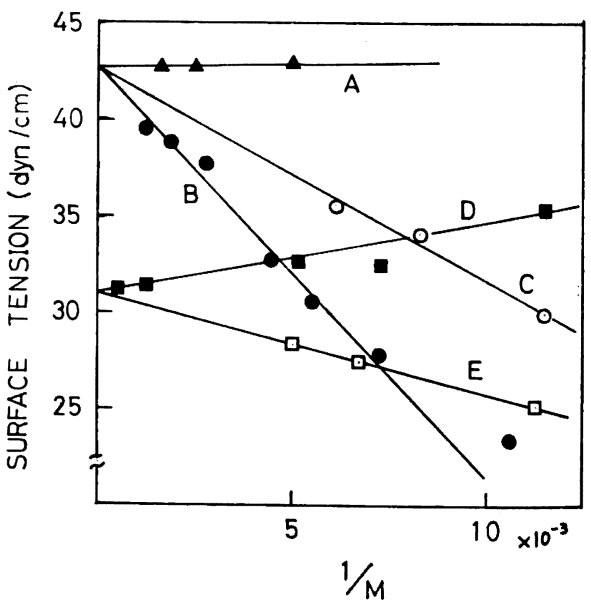

Fig. 8. Surface tension $v s .1 / M$ at $25^{\circ} \mathrm{C}$ : A, PEG series; B, PEG-DM series; C, EG-MM series; D, PPG series; E, PG-MM series. 
の $\beta$ と $\gamma_{\mathrm{o}} / \gamma_{\mathrm{m}}$ の指数の $1 / \beta$ とが互いに相殺しあうもの と思われる.

PEG 系, EG-MM 系および PEG-DM 系の $r$ の 分子量無限大 $(1 / M \rightarrow 0)$ への外そ5値は一致して, 42.7 $\mathrm{dyn} / \mathrm{cm}$ となり, PPG 系と PG-MM 系では $31.0 \mathrm{dyn} /$ $\mathrm{cm}$ となった.これは $M \rightarrow \infty$ では末端基の影響がなく なって, 同じ繰返し単位の寄与だけになるからである.

一方 $\gamma_{\mathrm{\theta}}$ は Fig. 8 の直線のこ5配から求めることがで きるが， $\beta$ に依存する．いま $\beta$ を 4 とおいて $\gamma_{\theta}$ の表面 張力に対する寄与を計算すると PPG 系では $43.2 \mathrm{dyn} /$ $\mathrm{cm}, \mathrm{PEG}-\mathrm{DM}$ 系では $12.0 \mathrm{dyn} / \mathrm{cm}$ である. $\beta$ の変 化を考虑に入れても， $\gamma_{\theta}(\mathrm{PEG}-\mathrm{DM})=11 \sim 13 \mathrm{dyn} / \mathrm{cm}$, $\gamma_{\mathrm{e}}(\mathrm{PPG})=42 \sim 44 \mathrm{dyn} / \mathrm{cm}$ となる.

PEG 系の末端基はPPG 系と同じ水酸基であるから, $\gamma_{\mathrm{e}}$ と $\gamma_{\mathrm{m}}$ はほぼ等しいから $\gamma$ の分子量依存性はない。 PEG-DM 系では $r_{\mathrm{e}}<r_{\mathrm{m}}$ となり, $r$ は $M$ とともに增 加する. また，PPG 系では $r_{\mathrm{e}}>r_{\mathrm{m}}$ となるから $\gamma_{\text {は } M}$ とともに減少する． EG-MM 系と PG-MM 系がと もに $\curlyvee は$ とともに增加するのは一端のメチル基が他 端の水酸基よりも効果的であるためと思われる.

\section{2 表面エネルギーと表面エントロピー}

Table 2 より明らかなことは表面エネルギー (表面過 剩エネルギー， $E^{S}$ ) は末端に水酸基をもつPEG 系) 70 $\left.72 \mathrm{erg} / \mathrm{cm}^{2}\right)$ の方が PEG-DM 系 $\left(55 \sim 65 \mathrm{erg} / \mathrm{cm}^{2}\right)$ 上 ク大きい. PPG の $E^{S}\left(56 \sim 65 \mathrm{erg} / \mathrm{cm}^{2}\right)$ が PEG 系よ り小さいのは側鎖メチル基の影響といえよう.

PEG 系む， PPG 系も分子量の增大とともに $E^{S}$ を 減少している.これは水酸基密度の減少と関保がある. これに対して EG-MM 系, PEG-DM 系および PGMM 系では分子量とともに $E^{S}$ が增大寸る. これも末 端メチル基密度の減少と関係があるであろら。この関係 が逆であるのは水酸基とメチル基の $E^{s}$ に対する寄与の 大小によっている.

一方, 表面エントロピー $\left(S^{S}\right)$ についてはいずれの場 合にも分子量とともに減少している. Starkweather ${ }^{\theta)} ら$ は $n$-alkane について $S^{S}$ が重合度の逆数に比例するこ とを示した. Fig. 9 に $S^{S}$ と 1/n の関係を示す. ほぼ 直線関保のあることが分かる.

\section{3 パラコールと比容}

表面張力とパラコールの間には前述のように Sugden の関係があるが，(3) 式の両辺の対数をとると $P, M$ は 定数であるから，

$$
\log \gamma=\beta \log \rho+c
$$

となる.ここでcは定数である.この式から $\log \gamma$ と $\log$ $\rho$ の間に比例関係が成り立ち，そのこう配が MacLeod 指数 ( $\beta$ ) である. 一例として, PEG-DM 采について $\log \gamma$ を $\log \rho$ に対してプロットすると Fig. 10 のよう

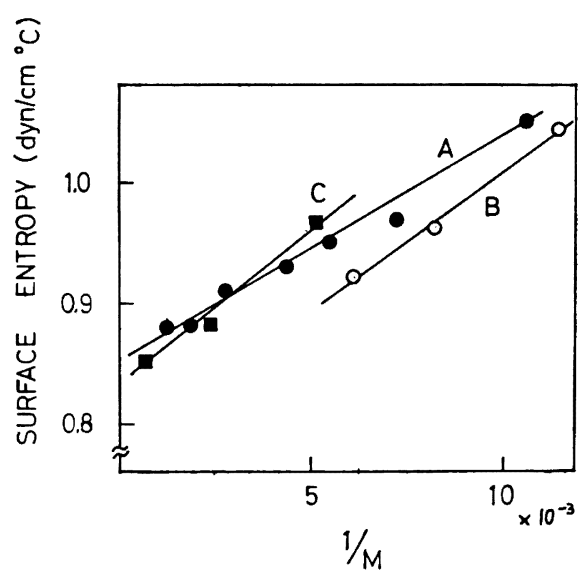

Fig. 9. Surface entropy vs. 1/M: A, PEG-DM series; B, EG-MM series; C, PPG series.

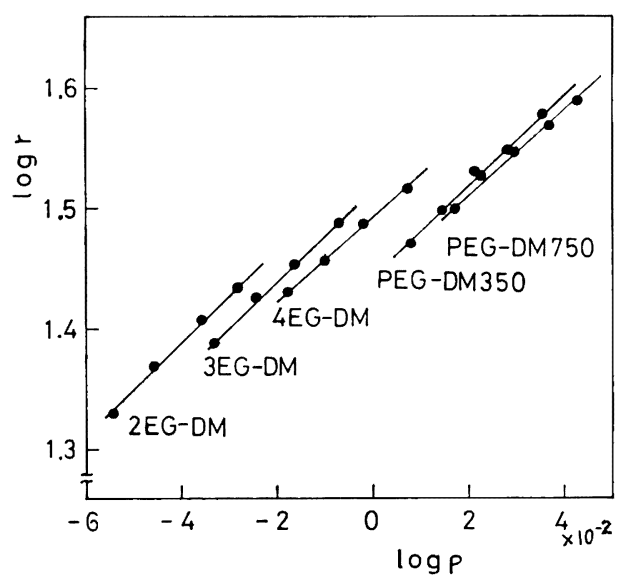

Fig. 10. $\log \gamma v s . \log \rho$ of PEG-DM series.

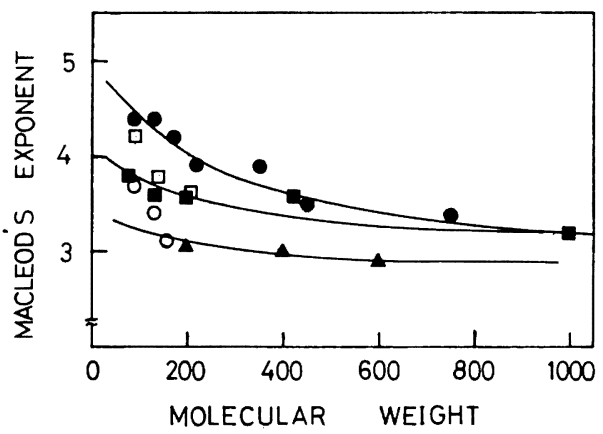

Fig. 11. Molecular weight dependence of MacLeod's exponent: $\mathbf{\Delta}$, PEG series; 9 , PEGDM series; $\bigcirc$, EG-MM series; $\square$, PPG series; $\square, P G-M M$ series. 
になる.この直線のこら配から求めた $\beta$ と分子量の関係 を Fig. 11 に示す. $\beta$ は $M$ とともに減少し, ほぼ 3 に 近づく．また (7) 式を温度 $(T)$ で微分すると,

$$
\begin{aligned}
\frac{\mathrm{d} \ln \gamma}{\mathrm{d} T} & =-\beta \frac{1}{\rho} \frac{\mathrm{d} \rho}{\mathrm{d} T} \\
& =-\alpha \cdot \beta
\end{aligned}
$$

となる.これは表面張力の自然対数の温度こう配は熱膨 張率と MacLeod 指数の積に等しいことを示するのであ る. Table 2 に本研究で用いた試料の $\alpha, \beta, \alpha \cdot \beta$ およ び $\mathrm{d} \ln \gamma / \mathrm{d} T$ の值を示す. 表から明らかなよらに $\alpha \cdot \beta$ と $\mathrm{d} \ln \gamma / \mathrm{d} T$ の值はほぼ一致した。

(5) 式を誘導するさいに，パラコールの加成性を仮定 したが，ここで加成性が成り立つことを示す。すなわ ち，(4) 式で指数 4 を一般に $\beta$ と批いて変形すると

$$
P=V \gamma^{1 / \beta}
$$

となる.この式を用いて測定された $V$ ととの值から $P$ を求めることができる，Fig. 12 は PEG-DM 系と PPG 系の $P$ を $M$ に対してプロットしたものである.

明らかに $P$ と $M$ の間に比例関係，才なわち加成性が 存在することが分かる。一方, 比容と分子量の関係は 烟消によって次式が示された.

$$
v=v_{\mathrm{m}}+\frac{2 k^{\prime}}{m+2 k^{\prime}}\left(v_{\mathrm{e}}-v_{\mathrm{m}}\right)
$$

ここで, $v$ は試料の比容， $v_{\mathrm{e}}, v_{\mathrm{m}}$ はそれぞれ末端基と 繰返し単位の比容, $m$ は繰返し単位の数, $k^{\prime}$ は繰返し 単位と末端基の分子量の比 $\left(M_{\mathrm{e}} / M_{\mathrm{m}}\right)$ である. Fig. 13 に $v$ と $2 k^{\prime} / m+2 k^{\prime}$ の関係を示したがよい直線関係のあ

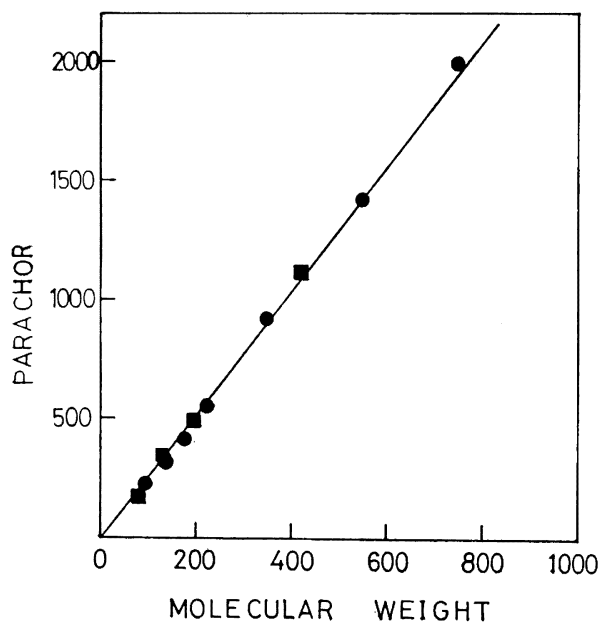

Fig. 12. Additivity of parachor: ๑, PEG-DM series; $\mathbf{\square}$, PPG series.

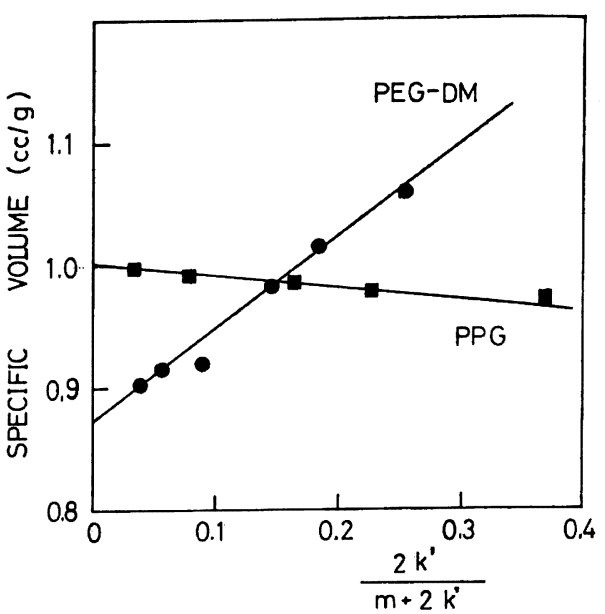

Fig. 13. Specific volume $v s .2 k^{\prime} /\left(m+2 k^{\prime}\right)$ of PEG$\mathrm{DM}$ series and PPG series at $25^{\circ} \mathrm{C}$.

ることが分かる. (10) 式から分かるよらに $2 k^{\prime} / m+2 k^{\prime} \rightarrow$ 0 一の外挿より $v_{\mathrm{e}}$ が求まり, 直線のこう配より $v_{\mathrm{m}}$ が 求まる。 これより求めた $25^{\circ} \mathrm{C}$ に打ける PEG-DM 系 の末端基の分子容は $24.7 \mathrm{cc}$, 繰返し単位の分子容は $38.2 \mathrm{cc}$ となった。 Krevelen ${ }^{10)}$ らによれば, メチル基 の分子容は $22.1 \mathrm{cc}$ であり, PEG-DM 系の末端基は若 干大きくなった．ここで， $k^{\prime}$ の值を求めるのに PEG$\mathrm{DM}$ 系の末端をメチル基として計算したが， $-\mathrm{CH}_{3}$ と すべきか $-\mathrm{OCH}_{3}$ とするべきかは問題である. 彼らは 一Oーの $V$ に対する寄与を $7.6 \mathrm{cc}$ としているが，こ れを用いると $-\mathrm{OCH}_{3}$ の $V$ は $29.3 \mathrm{cc}$ である. これ より考えられることは，末端基を一 $-\mathrm{OCH}_{3}$ とすること はできないが，一Oーの回転性が末端メチル基の $V$ に 対して相当の寄与をしていることが分かる， $\gamma_{\mathrm{m}}$ につい ては, Krevelen らの - $\mathrm{CH}_{2}$ 一, と一O-に対する值 を加光合わせると $-\mathrm{CH}_{2}-\mathrm{CH}_{2}-\mathrm{O}-$ - $V$ は $39.8 \mathrm{cc}$ となり, 我々の值とほぼ一致する。

一方, PPG 系の $V_{\mathrm{e}}$ は $15.5 \mathrm{cc}, V_{\mathrm{m}}$ は $58.0 \mathrm{cc}$ で あるが，Krevelen らの值を求めると一 - $\mathrm{OH} の V$ は $14.5 \mathrm{cc},-\mathrm{CHCH}_{3}-\mathrm{CH}_{2}-\mathrm{O}$ 一 の $V$ は $57.3 \mathrm{cc}$ とな り我々の値と一致する.

\section{4 表面張力と表面エントロピーに及ほすメチル基 の効果}

PEG 系と PPG 系の $V$ の $M \rightarrow \infty$ への外そう值と PIBG の $r$ を比較すると, 側鎖メチル基の数の増加に従 って $r$ の值は $42.7 \mathrm{dyn} / \mathrm{cm}$ から $27.2 \mathrm{dyn} / \mathrm{cm}$ 一減少 する. 北崎 ${ }^{11)}$ はポリエチレン(PE), ポリプロピレン(PP), ポリイソブチレン(PIB) のてを比較し，PPは PE より 6 dyn $/ \mathrm{cm}$ 小さいが, PIB はPP よりメチル基が 1 個多 いにもかかわらず $\gamma$ は $2 \mathrm{dyn} / \mathrm{cm}$ 大きくなることを示 
エチレングリコール，プロピレングリコールおよびそのメチルエーテル同族体の表面張力

Table 3. Effect of methyl group on surface tension in repeating unit and terminal group of polyethers at $25^{\circ} \mathrm{C}$.

\begin{tabular}{|c|c|c|}
\hline Sample & $r_{m}(\operatorname{dyn} / \mathrm{cm})$ & $\gamma_{e}(\mathrm{dyn} / \mathrm{cm})$ \\
\hline & $\mathrm{CH}_{3}$ & \\
\hline PIBG & $27.2\left(-\mathrm{C}-\mathrm{CH}_{2}-\mathrm{O}-\right)$ & $42 \sim 44(-\mathrm{OH})$ \\
\hline PPG & $31.0\left(-\mathrm{CH}-\mathrm{CH}_{2}-\mathrm{O}-\right)$ & $42 \sim 44(-\mathrm{OH})$ \\
\hline PEG & $42.7\left(-\mathrm{CH}_{2}-\mathrm{CH}_{2}-\mathrm{O}-\right)$ & $42 \sim 44(-\mathrm{OH})$ \\
\hline PEG-DM & $42.7\left(-\mathrm{CH}_{2}-\mathrm{CH}_{2}-\mathrm{O}-\right)$ & $11 \sim 13\left(-\mathrm{CH}_{3}\right)$ \\
\hline
\end{tabular}

した、ポリエーテルでこのようなことが生じないのは, エーテル結合による分子内回転の自由度が大きいのでメ チル基の効果が制限されないためと考えられる.

一方, 表面エントロピーは PEG 600 で $0.0945 \mathrm{dyn} /$ $\mathrm{cm}^{\circ} \mathrm{C}$, PPG 1025 の $0.085 \mathrm{dyn} / \mathrm{cm}^{\circ} \mathrm{C}$, PIBG 0.062 $\mathrm{dyn} / \mathrm{cm}{ }^{\circ} \mathrm{C}$ のようにメチル基の增加とともに減少して いる. 側鎖メチル基についてはこの他に PE の 0.060 $\mathrm{dyn} / \mathrm{cm}{ }^{\circ} \mathrm{C}$ が PP の $0.058 \mathrm{dyn} / \mathrm{cm}{ }^{\circ} \mathrm{C}$, ポリスチレン の $0.071 \mathrm{dyn} / \mathrm{cm}{ }^{\circ} \mathrm{C}$ がポリ- $\alpha$-メチルスチレンの 0.058 $\mathrm{dyn} / \mathrm{cm}{ }^{\circ} \mathrm{C}$ のよらにメチル基の増加とともに減少する ことが示されている.これに対して末端×チル基につい てみると，EG-MM 系，PEG-DM 系，PG-MM 系 のいずれの場合にも分子量の增加，すなわちメチル基の 分率の減少に伴い $S^{S}$ は減少している. 以上のように末 端メチル基は $S^{S}$ を增加させるが，側鎖メチル基は $S^{S}$ を滅少させる効果がある，ポリェーテルの側鎖，または

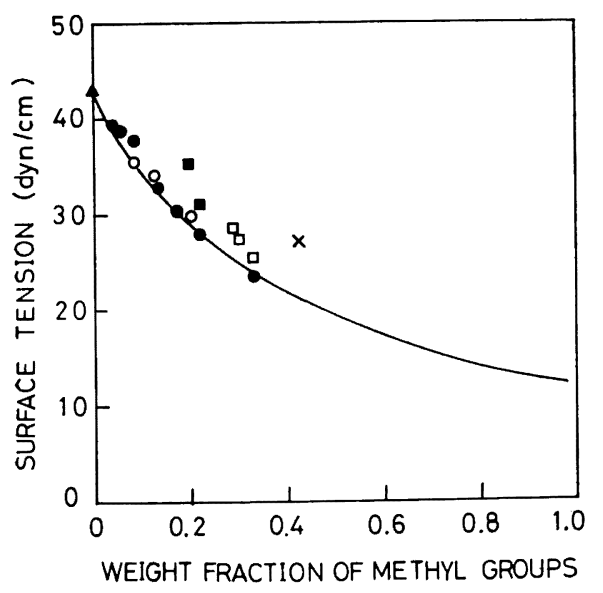

Fig. 14. Surface tension $v s$. weight fraction of methyl groups intra molecule: $\bullet$, PEGDM series; $O$, EG-MM series; $\mathbf{\square}$, PPG series; $\square$, PG-MM series; $\times$, PIBG.
末端にメチル基を導入したときの $V$ に及ぼす繰返し単 位の $\gamma_{\mathrm{m}}$ と末端基の $V_{\mathrm{e}}$ の相互関保を表示すると Table 3 のようになる，表にみるように，ポリエーテルではねチ ル基は繰返し単位に対しても末端基に対してもてを低下 させるように作用する。

メチル基の界面活性作用は次の事実によっても示され る. Fig. 14 は分子内に批るメチル基の重量分率に対 するrの变化を示す図である. 明らか汇とチ儿基の分率 の大きなものが小さい、ををもつことが分かる、また同じ メチル基分率をもつものでも末端メチル基の方が側鎖メ チル基より界面活性であることが分かる。このことは末 端メチル基の方が自由体積が大きく，分子容に対する寄 与が側鎖メチル基より大きいことから説明できる。すな わち (2) 式より明らかなよらに，分子容が大きくなれば 表面張力は小さくなる.よって末端入チル基の方が側鎖 メチル基より界面活性となる。

\section{5 結論}

本研究はポリエチレングリコールとそれを主鎖として 末端または側鎖としてメチル基をもつ種々のポリエーテ ルについて表面張力を測定し，その分子量依存性扰よび それに及ぼすメチル基の効果について論じたものであ る.

(1) PEG 系については表面張力の分子量に上る顕著 な変化はみられなかった，EG-MM 系, PEG-DM 系, PG-MM 系のように末端にメチル基を有するものの表 面張力は分子量とともに增加し, PPG 系については減 少した.このことは畑の導いた(5)式によって合理的に説 明できた. PEGーDM 系の末端の表面張力は $12.0 \mathrm{dyn} /$ $\mathrm{cm}$ PPG 系のそれは 42 44 dyn $/ \mathrm{cm}$ と推定された.

(2) 表面張力と分子量の逆数の間には直線関倸が存在 する. $\mathrm{EG}-\mathrm{MM}$ 系と $\mathrm{PEG}-\mathrm{DM}$ 系の表面張力の $1 / M$ $\rightarrow 0$ 人の外そう值は PEG 系の表面張力に一致し，PG一 MM 系沈いては PPG 系の值に一致した。

(3) パラコールと比容については加成性が成立する. 
PEG-DM 系の末端基の分子容は $24.2 \mathrm{cc}$, 繰返し単位 のそれは $38.2 \mathrm{cc}$ となった. また PPG 系の $V_{\mathrm{e}}$ は $14.5 \mathrm{cc}, V_{\mathrm{m}}$ は $57.3 \mathrm{cc}$ となった.

（4）繰返し単位当りのメチル基の数が増えるに従って 表面張力および表面ェントロビーはともに減少した.

謝 辞 本研究に用いたポリイソブチレングリコール の試料を提供していただいたダイセル(株) 中央研究所の 田中一伸, 塚根永芳の両氏に感謝の意を表します。

\section{文献}

1) A. K. Rastogi, L. E. ST. Pierre: J. Colloid and Interface Sci., 35, 16 (1972).

2) 烟敏雄: 高分子, 17, 549 (1968).

3) 畑 敏雄: 表面, 6, 281 (1968).
4) A.W. Poter: Phil. Mag., 15, (1933).

5) A. F. Gallaugher, H. Hibbert: J. Amer. Chem. Soc., 59, 2514 (1937).

6) F. B. Garner, S. Sugden: J. Chem. Soc., 1298 (1929).

7) W. D. Bascom, R. L. Cottington, C. R. Singleterry: "Contact Angle Wettability and Adhesion", pp. 355 (1964), Am. Chem. Soc.

8) D.G. Legrand, G.L. Gains: J. Colliod and Interface Sci., 31, 162 (1969).

9) H. Starkweather: SPE Transactions, 5, No. 1, 5 (1965).

10) D.W. Van Krevelen, P.J. Hoftyzer: J. Appl. Polymer Sci., 13, 87 (1969).

11) 北崎察昭：昭和 47 年東京工業大学博士論文.

Surface Tension of Poly(ethylene glycol), Poly(propylene glycol) and Their Methyl Ether Homologous -Molecular Weight Dependence and Methyl Group Effect

Tomoyuki Kasemura*1 and Toshio HATA*2

*1Department of Textile Industry, Faculty of Engineering, Gifu University (Kakamigahara, Gifu 504)

*2 Department of Textile Industry, Faculty of Engineering, Gunma University (Tenjincho, Kiryu 376)

Surface tension $r$ of poly(ethylene glycol) (I), poly(propylene glycol) (II) and their methyl ether homologous was measured by the sessile bubble method at various temperatures and the molecular weight dependence of the surface tension and the methyl group effect are discussed. $r$ of $I$ is independent of the molecular weight (MW), and increases with $\mathrm{MW}$ for the monomethyl and dimethyl ethers of $\mathbf{I}$. In the case of II series, it decreases with MW for II and increases for the monomethyl ethers of II. These facts are explained by the Hata's formula based on the additivity of $r$ component of the repeating unit and the terminal group. Methyl group acts as decreasing $\gamma$ both in repeating unit and in terminal groups. $\gamma$ of repeating unit of I, II and polyisobutylene glycol is estimated as $42.7,31.0$ and $27.2 \mathrm{dyn} / \mathrm{cm}$ respectively, and $\gamma$ of terminal hydroxy group and methoxy group is $42-44$ and 11$13 \mathrm{dyn} / \mathrm{cm}$. Additivity of parachor and molecular volume is also shown. MacLeod's exponent $(\beta)$ decreases with MW and the relation of $\mathrm{d} \ln \gamma / \mathrm{d} T=\alpha \beta$, where $\alpha$ is thermal expansion coefficient, is verified experimentally.

KEY wORDS Surface tension / Surface entropy / MacLeod's exponent / Parachor / Thermal expansion coefficient /

(Received December 15, 1975: Accepted January 28, 1976)

[Kobunshi Ronbunshu, 33(4), 192-200 (1976)] 